\title{
Risk factors associated with early failure of dental implants. A literature review
}

\author{
Cristina Palma-Carrió ${ }^{1}$, Laura Maestre-Ferrín ${ }^{2}$, David Peñarrocha-Oltra ${ }^{1}$, María A. Peñarrocha-Diago ${ }^{3}$, \\ Miguel Peñarrocha-Diago ${ }^{4}$
}

\footnotetext{
${ }^{1}$ Student of Master of Oral Surgery and Implantology, Valencia University Medical and Dental School, Valencia, Spain

${ }^{2}$ Master of Oral Surgery and Implantology, Valencia University Medical and Dental School, Valencia, Spain

${ }^{3}$ Professor Assistant of Oral Surgery. Master of Oral Surgery and Implantology, Valencia University Medical and Dental School, Valencia, Spain

${ }^{4}$ Professor, Director of the Master of Oral Surgery and Implantology, Valencia University Medical and Dental School, Valencia, Spain
}

Correspondence:

Clínica Odontológica,

Gascó Oliag, 1 ,

46021-Valencia (Spain)

maria.penarrocha@uv.es

Received: 15/02/2010

Accepted: 26/08/2010

Palma-Carrió C, Maestre-Ferrín L, Peñarrocha-Oltra D, Peñarrocha-Diago MA, Peñarrocha-Diago M. Risk factors associated with early failure of dental implants. A literature review. Med Oral Patol Oral Cir Bucal. 2011 Jul 1;16 (4):e514-7.

http://www.medicinaoral.com/medoralfree01/v16i4/medoralv16i4p514.pdf

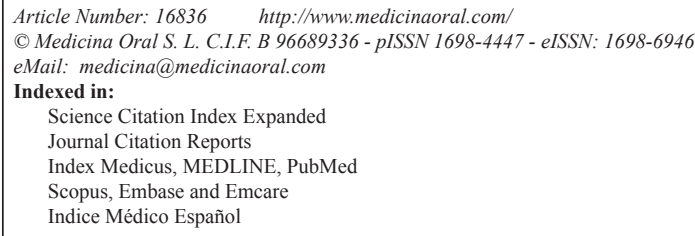

\begin{abstract}
The aim of the study was to examine articles published on risk factors associated with early failure of dental implants. We conducted a search on PubMed for articles published between January 2000 and December 2009 using the keywords 'dental implants' and 'early failure'. Seven studies that specified the number of early failed implants and studied the associated risk factors were included.

Early failures are caused by the inability of tissue to establish osseointegration prior to prosthetic restoration; however the causal factors and mechanisms are unclear. In the reviewed literature there was a higher percentage of early than late failures; nevertheless, few articles were found that analyzed risk factors associated with early implant failure. In the majority of studies, statistically significant factors associated with early implant failure were smoking, quantity and quality of bone, and posterior implant location. The low number of studies in the literature does not allow definitive conclusions to be drawn.
\end{abstract}

Key words: Dental implant, early failure, osseointegration, risk factors.

\section{Introduction}

Biological failure of implants can be defined as the inability of tissue to establish or maintain osseointegration. These failures are classified into early (failure to establish osseointegration) and late (failure to maintain osseointegration). One way to differentiate early and late failures is to define the early group as implants removed before prosthetic restoration, while those occurring after prosthetic rehabilitation are classified as late (1). Early failures are characterized by minimal bone loss and predomination in female and younger patients. According to a study by Manor et al. (2), the most common causes of late failures were periimplantitis, and implant overloading and fracture. However, the principal cause 
of early failure was the lack of osseointegration. Early failures are caused by the inability to establish a close contact between bone and implant (1) due to the absence of bone apposition and the formation of scar tissue between the surface of the implant and surrounding bone (3). Esposito et al. (1) noted that surgical trauma and bone quality and quantity were the most important etiological factors involved in early implant failures.

In the majority of studies, success rates are calculated from the time of implant loading and full functionality, therefore little information is available on implant failures prior to loading (4).

Few studies (5-11) analyze early failure of implants and study the related risk factors. Other studies (12-15), specify the number of early and late failures, and indicate the risk factors related with the total number of failures. In these studies early failure rates vary from 1.2 to $3 \%$ and late failure rates from 0 to $1.8 \%$, early failures being more frequent than late (12-17).

The causes and mechanisms of early implant failure are unclear, different studies (5-11) have found a variety of statistically significant factors associated with early implant failure, these are: age and sex (11), systemic diseases $(8,9)$, smoking $(5-7,9,10)$, type of edentulism $(8,9)$, maxillary implant location (6), quantity and quality of bone (5-8), and implant length and diameter $(7,8)$. Immunological $(4,5)$, and genetic factors (18) have also been associated with early implant failure.

The aim of this study was to review the literature on risk factors associated with implant failure during the osseointegration period.

\section{Search Methodology}

The PubMed database was searched for studies published between January 2000 and December 2009 using the keywords 'dental implants' and 'early failure'. Studies that specified the number of early failed implants and studied the associated risk factors were included. Eight studies that did not specify the number of failed implants, five that did not associate specific risk factors with early failure, five studies where the full text could not be obtained, eight revisions, and two studies on animals were all excluded. A total of seven studies were included (5-11).

\section{Risk factors associated with early implant failure} Studies that assess the risk factors associated with early failure of implants are shown in table 1 (5-11).

In most studies (6, 8-10), age and sex are not related with early implant failure. Noguerol et al. (7) had more failures in patients aged 41-60 years than in patients aged over 60 , indicating that older age is not contraindicative to implant treatment. Sverzut et al. (11) observed that the possibility for early failure of implants is increased by a factor of 1.0750 for each additional year in patient age. Regarding gender, these same authors found that men had a 1.255 times greater risk of early implant failure than women.

The influence of systemic factors in the osseointegration process is poorly documented $(6), 3$ studies $(6,8,9)$ were found that related systemic diseases with early implant failure. In a retrospective study, Alsaadi et al. (8) noted that Crohn's disease and osteoporosis were as-

Table 1. Studies that evaluated risk factors associated with early failure of dental implants.

\begin{tabular}{|c|c|c|c|c|c|c|c|c|c|c|c|c|}
\hline \multirow[b]{2}{*}{ Author } & \multirow[b]{2}{*}{ Year } & \multirow{2}{*}{$\begin{array}{c}\mathrm{N}^{0} \\
\text { patient }\end{array}$} & \multirow{2}{*}{$\begin{array}{c}\mathrm{N}^{\circ} \\
\text { implant } \\
\text { placed }\end{array}$} & \multirow{2}{*}{$\begin{array}{l}N^{0} \text { early } \\
\text { failures }\end{array}$} & \multicolumn{8}{|c|}{ Risk factors associated with early failure of dental implants. } \\
\hline & & & & & $\begin{array}{c}\text { Age } \\
\text { and sex }\end{array}$ & SD & Smoking & $D$ and $L$ & $\begin{array}{c}\text { Type of } \\
\text { edentulism }\end{array}$ & $\begin{array}{l}\text { Bone quality } \\
\text { and quantity }\end{array}$ & \begin{tabular}{l|} 
Implant \\
location
\end{tabular} & Others \\
\hline $\begin{array}{l}\text { Kronström M } \\
\text { et al. (5) }\end{array}$ & 2001 & * & $*$ & $*$ & $\cdots$ & $\cdots$ & + & - & - & + & - & $\begin{array}{l}\text { Immunological } \\
\text { factors }\end{array}$ \\
\hline $\begin{array}{c}\text { van } \\
\text { Steenberghe } \\
\text { et al. (6) }\end{array}$ & 2002 & 399 & 1263 & $27(2,2 \%)$ & - & - & + & $\ldots$ & - & + & + & $\begin{array}{l}\text { Chemotherapy, } \\
\text { radiotherapy }\end{array}$ \\
\hline $\begin{array}{l}\text { Alsaadi et al. } \\
\text { (8) }\end{array}$ & 2007 & 2004 & 6946 & $252(3,6 \%)$ & - & + & + & + & + & + & + & Periotest ${ }^{\mathbb{B}}$ Value \\
\hline $\begin{array}{l}\text { Alsaadi et al. } \\
\text { (9) }\end{array}$ & 2008 & 283 & 720 & $14(1,9 \%)$ & - & + & + & + & + & - & - & $\begin{array}{l}\text { Apical lesions, } \\
\text { hormone } \\
\text { replacement therapy }\end{array}$ \\
\hline $\begin{array}{l}\text { Sverzut et al. } \\
\text { (11) }\end{array}$ & 2008 & 650 & 1628 & $50(3,07 \%)$ & + & $\ldots$ & - & + & $\cdots$ & $\cdots$ & + & $\begin{array}{c}\text { Bone grafting, } \\
\text { alveolar distraction, } \\
\text { and postoperative } \\
\text { infection }\end{array}$ \\
\hline
\end{tabular}

... Not evaluated

+ Statistically significant $(\mathrm{p}<0.05)$

- Not statistically significant ( $\mathrm{p}>0.05)$

*Study group: 40 adults with early implants failures; Control group: 40 adults with succesfully osseointegrated dental implants.

SD: Systemic disease

D and L: Diameter and lenght 
sociated with increased implant failure; and that gastric and cardiac disease, controlled diabetes type I and II, problems with coagulation, hypertension, hypo- or hyperthyroidism, hypercholesterolemia, asthma, and claustrophobia were not related. However, in a prospective study, Alsaadi et al. (9) found a relationship between increased early implant failure and gastric problems, Crohn's disease, diabetes type I, and women with radical hysterectomy. Regarding diabetes, a review by Mellado-Valero et al. (19) found more failures in diabetic patients compared to the general population, the majority during the first year of functional loading. In a study by van Steenberghe et al. (6), chemotherapy and radiotherapy of oral tissues were significantly related to implant failure $(\mathrm{p}<0.01)$; and patients with claustrophobia had more failures as surgery was carried out under insufficiently sterile conditions.

Regarding smoking, some studies $(7,9,10)$ found significantly more failures in heavy smokers $(>20$ cigarettes $/$ day) than in nonsmokers; early failure of implants was related to smoking and increased with cigarette consumption (9). van Steenberghe et al. (6) found that approximately one in every three implant failures occurred in smokers, and one in five patients with early failures smoked over 10 cigarettes per day, while only $12.3 \%$ of patients without failures were smokers. Konstrom et al. (4) found an association with smoking although it was not the most important factor. In contrast, Sverzut et al. (11) did not observe any statistically significant association between smoking and early implant failures, concluding that smoking alone cannot be considered a risk factor for early failure of implants.

Alsaadi et al. $(8,9)$ considered the type of edentulism to be a risk factor for implant failure, these authors classified implant failure according to the presence and location of natural teeth in the oral cavity and the relation to implant location: full edentulism, teeth present in the opposing arch, teeth in the same arch without being adjacent to the implant, and natural teeth adjacent to the implant; observing a significant increase in failures of implants placed adjacent to teeth.

Regarding the implant location, three times more failures have been observed in the maxilla than the mandible (1). In a study by van Steenberghe et al. (6), approximately half the early failures occurred in the posterior maxilla. When comparing success rates, the posterior maxillary region had a success rate of $91.4 \%$ compared to the anterior maxillary region with $97 \%, 96.3 \%$ in the posterior mandible and $97.9 \%$ in the anterior mandible. Alsaadi et al. (8) found significantly more failures in the posterior region of both jaws compared to the anterior mandibular region. However, in a prospective study by Alsaadi et al. (9), the implant site was not a significant factor in implant failure.

Regarding bone quality and quantity, Konstrom et al. (5) observed a statistically significant difference in values for bone quality, shape and resorption between the osseointegrated implants group and the group with at least one failed implant, indicating increased risk in resorbed maxillae. In a study by Noguerol et al. (7), implants that were not placed in type II bone had a 1.93 times greater probability of early failure. In a study by Alsaadi et al. (8), bone quality types I and IV according to the Lekholm and Zarb classification were associated with increased failure. van Steenberghe et al. (6), observed that half the failures were in poor quality bone (types IIIIV), and that bone of limited quantities showed a similar trend $(\mathrm{p}<0.01)$. Nevertheless, in a study by Alsaadi et al. (9), poor bone quality did not affect the percentage of early implant failures.

Regarding implant dimensions, Alsaadi et al. (9) found more failures in short $(<10 \mathrm{~mm})$ and large diameter $(5 \mathrm{~mm})$ implants; these implants were placed systematically in compromised sites with poor bone quality and quantity, which may explain the high failure rates. Noguerol et al. (7) observed an increased risk of implant failure in implants less than $15 \mathrm{~mm}$ in length and over $4 \mathrm{~mm}$ in diameter. However, in a prospective study, Alsaadi et al. (8) found that implant length and diameter had no significant effect on early failure.

Other considerations, such as immunological factors (5) and the Periotest ${ }^{\circledR}$ value (Siemens AG, Bensheim, Germany) $(7,8)$ have been associated with early implant failure. For Konstrom et al. (5), the presence of antibodies to B. forsythus and S. aureus were the most important factors associated with early failure of implants. In a study by Noguerol et al. (7), the Periotest ${ }^{\circledR}$ value obtained during first surgery was the most effective method for prediction and early diagnosis of implant failure compared with intraoral radiography. Alsaadi et al. (8) observed more implant failures with increased Periotest $^{\circledR}$ values at the time of implant placement. Other factors such as the presence of apical lesions, hormone replacement therapy (9), bone grafting, alveolar distraction, and postoperative infection have also been associated with implant failure (11).

\section{Conclusion}

The reviewed literature reveals a greater number of early than late failures; nevertheless, very few studies specify the risk factors associated with early implant failures. In the publications included in this study, smoking, posterior location of the implant, and bone quantity and quality were most related to implant failure. These findings are not definitive, since a larger number of studies that evaluate the various factors associated with implant failure are needed. 


\section{References}

1. Esposito M, Hirsch JM, Lekholm U, Thomsen P. Biological factors contributing to failures of osseointegrated oral implants. (I). Success criteria and epidemiology. Eur J Oral Sci. 1998;106:527-51.

2. Manor Y, Oubaid S, Mardinger O, Chaushu G, Nissan J. Characteristics of early versus late implant failure: a retrospective study. J Oral Maxillofac Surg. 2009 ;67:2649-52.

3. Esposito M, Thomsen P, Ericson LE, Lekholm U. Histopathologic observations on early oral implant failures. Int J Oral Maxillofac Implants. 1999;14:798-810.

4. Kronström M, Svensson B, Erickson E, Houston L, Braham P, Persson GR. Humoral immunity host factors in subjects with failing or successful titanium dental implants. J Clin Periodontol. 2000;27:875-82.

5. Kronström M, Svenson B, Hellman M, Persson GR. Early implant failures in patients treated with Brånemark System titanium dental implants: a retrospective study. Int J Oral Maxillofac Implants. 2001;16:201-7.

6. Van Steenberghe D, Jacobs R, Desnyder M, Maffei G, Quirynen $\mathrm{M}$. The relative impact of local and endogenous patient-related factors on implant failure up to the abutment stage. Clin Oral Implants Res. 2002;13:617-22.

7. Noguerol B, Muñoz R, Mesa F, de Dios Luna J, O’Valle F. Early implant failure. Prognostic capacity of Periotest: retrospective study of a large sample. Clin Oral Implants Res. 2006;17:459-64.

8. Alsaadi G, Quirynen M, Komárek A, Van Steenberghe D. Impact of local and systemic factors on the incidence of oral implant failures, up to abutment connection. J Clin Periodontol. 2007;34:610-7. 9. Alsaadi G, Quirynen M, Michiles K, Teughels W, Komárek A, van Steenberghe D. Impact of local and systemic factors on the incidence of failures up to abutment connection with modified surface oral implants. J Clin Periodontol. 2008;35:51-7.

10. Bornstein MM, Halbritter S, Harnisch H, Weber HP, Buser D. A retrospective analysis of patients referred for implant placement to a specialty clinic: indications, surgical procedures, and early failures. Int J Oral Maxillofac Implants. 2008;23:1109-16.

11. Sverzut AT, Stabile GA, de Moraes M, Mazzonetto R, Moreira RW. The influence of tobacco on early dental implant failure. J Oral Maxillofac Surg. 2008;66:1004-9.

12. Testori T, Wiseman L, Woolfe S, Porter SS. A prospective multicenter clinical study of the Osseotite implant: four-year interim report. Int J Oral Maxillofac Implants. 2001;16:193-200.

13. Davarpanah M, Martinez H, Etienne D, Zabalegui I, Mattout $\mathrm{P}$, Chiche $\mathrm{F}$, et al. A prospective multicenter evaluation of 1,583 $3 \mathrm{i}$ implants: 1- to 5-year data. Int J Oral Maxillofac Implants. 2002;17:820-8.

14. Roos-Jansåker AM, Lindahl C, Renvert H, Renvert S. Nine- to fourteen-year follow-up of implant treatment. Part I: implant loss and associations to various factors. J Clin Periodontol. 2006;33:283-9.

15. Koldsland OC, Scheie AA, Aass AM. Prevalence of implant loss and the influence of associated factors. J Periodontol. 2009;80:106975.

16. Huynh-Ba G, Friedberg JR, Vogiatzi D, Ioannidou E. Implant failure predictors in the posterior maxilla: a retrospective study of 273 consecutive implants. J Periodontol. 2008;79:2256-61.

17. Martínez-González JM, Barona-Dorado C, Cano-Sánchez J, Flórez-Rodríguez M, Cantero-Alvarez M. Clinical and radiographic behaviour of 290 dental implants with a surface treated with hydrofluoric acid and passivated with hydrofluoric and nitric acid: early loading results after 2 years. Med Oral Patol Oral Cir Bucal. 2005;10:355-61.

18. Leite MF, Santos MC, De Souza AP, Line SR. Osseointegrated implant failure associated with MMP-1 promotor polymorphisms (-1607 and -519). Int J Oral Maxillofac Implants. 2008;23:653-8.

19. Mellado-Valero A, Ferrer García JC, Herrera Ballester A, Labaig Rueda C. Effects of diabetes on the osseointegration of dental implants. Med Oral Patol Oral Cir Bucal. 2007;12:E38-43. 